\title{
ANALISIS KOMODITAS POTENSIAL PEMBENTUKAN PASAR LELANG Studi Kasus di Kabupaten Kerinci dan Merangin
}

\author{
Oleh: \\ Ahmad Soleh \\ Dosen Tetap STIE Muhammadiyah Jambi \\ mas.soleh@yahoo.com \\ Ringkasan
}

Pasar lelang merupakan sarana utama dalam membantu mendekatkan antara produsen dengan konsumen dalam memangkas alur pasar dari produsen sehingga lebih menguntungkan. Pasar lelang berfungsi dalam meminimalisisr dari rentetan rentenir yang mengurangi pendapatan petani. Melalui pasar lelang komoditas, negosiasi antara produsen dan konsumen lebih transparan dan dapat menguntungkan kedua pihak.

Ada empat manfaat utama ari keberadaan pasar lelang diantaranya: (1) terciptanya transparansi harga dalam perdagangan hingga ke tingkat produsen, (2) meningkatkan efisiensi tata niaga, (3) meningkatkan posisi rebut tawar (bargaining position) mendorong perolehan harga yang lebih tinggi yang kemudian diharapkan dapat meningkatkan pendapatannya, dan (4) dapat menjadi pendorong peningkatan mutu dan produksi petani. Atas dasar manfaat tersebut maka dilakukannya penelitian tentang beberapa hal yang mendasari dalam pembentukan pasar lelang di Provinsi Jambi.

Jenis data yang digunakan dalam penelitian ini adalah data sekunder dan data primer yang dikumpulkan dari beberapa berbagai sumber yang terkait dengan penelitian ini. Sementara metode analisis data yang digunakan dalam penelitian ini adalah metode deskriptif kualitatif dan kuantitaf dengan ruang lingkup penelitian meliputi data komoditas seluruh kecamatan di wilayah Kabupaten Kerinci dan Kabupaten Merangin. Dengan produk unggulan daerah yaitu Kopi (kopi robusta, arabika dan liberika) dan kayu manis.

Hasil penelitian menunjukkan berdasarkan: (1) Kontinuitas Produksi Komoditi (2) harga jual petani (3) distribusi pemasaran hasil produksi, (4) Hasil produksi dan (5) kesepakatan petani maka dapat disimpulkan pembentukan pasar lelang dapat dilakukan pada tingkat kecamatan sesuai dengan tigkat kecamatan yang memenuhi standar diatas.

Kata kunci : Pembentukan Pasar Lelang.

\section{PENDAHULUAN}

Provinsi Jambi sebagai salah satu kawasan pembangunan di wilayah Sumatera memiliki sumberdaya alam yang kaya, terutama pada sektor pertanian dan perkebunan berupa tanaman pangan, komoditas kelapa sawit, karet, teh, kopi, palawija, dan sebagainya. Pemanfaatan potensi alam secara maksimal untuk mengelola hasil-hasil pertanian dan perkebunan tentu akan berdampak pada tingkat kesejahteraan petani. Namun dalam hal ini ada beberapa kendala yang masih dialami petani, yaitu masalah harga jual. Saat ini hasil-hasil perkebunan masih di terima oleh petani dengan harga jual yang rendah, karena rata-rata petani menjual hasil perkebunan melalui pedagang perantara, dan rantai tata niaga barang hingga sampai kepada konsumen 
dapat melalui jenjang mata rantai perdagang yang panjang maupun pendek. Dan hal ini yang mempengaruhi tingkat harga yang diterima oleh petani.

Pedagang perantara yang selalu berusaha memperoleh keuntungan dari margin antara harga ditingkat konsumen akhir (eksportir/pabrik pengelola) dengan harga ditingkat produsen, mendorong terjadinya harga beli ditingkat petani yang cenderung rendah. Oleh karena itu memangkas panjang rantai tata niaga yang berdampak pada harga jual petani, maka pemerintah mengeluarkan kebijakan untuk mengadakan pasar lelang untuk beberapa komoditi dari hasilhasil perkebunan.

Pasar lelang adalah wahana bertemunya para pembeli dan penjual dengan menggunakan sistem lelang dengan penyerahan kemudian, pada pelaksanaannya hanya dalam bentuk kontrak kerja sama kedua belah pihak. Di pasar lelang pedagang hanya membawa contoh produknya saja, jika pembeli berkenan pada saat itu dilakukan kontrak untuk mendrop barang pada waktu yang disepakati, biasanya produk dalam jumlah besar

Tujuan dari pasar lelang, guna membantu mendekatkan antara produsen dengan konsumen, artinya untuk memangkas alur pasar sehingga dapat saling menguntungkan. Karena melalui pola program pasar lelang komoditas transaksi antara penjual dan pembeli sudah dapat diminimalisir dari rentetan rentenir, sehingga kesejahteraan petani atau usaha kecil akan semakin meningkat. Selain itu, dengan adanya pasar lelang komoditas, negosiasi antara produsen dan konsumen lebih transparan sehingga tak menguntungkan sepihak saja.

Pasar lelang tersebut merupakan suatu bentuk pasar yang teratur (organized market), yang ditujukan untuk rnemperoleh manfaat berupa (1) terciptanya transparansi harga dalam perdagangan hingga ke tingkat produsen, (2) meningkatkan efisiensi tata niaga, (3) meningkatkan posisi rebut tawar (bargaining position) mendorong perolehan harga yang lebih tinggi yang kemudian diharapkan dapat meningkatkan pendapatannya, dan (4) dapat menjadi pendorong peningkatan mutu dan produksi petani. Jika tujuan tersebut dapat dicapai, diharapkan tingkat pendapatan petani akan meningkat.

Ada beberapa produk perkebunan yang potensial namun belum diadakan pasar lelang dan pada penelitian ini produk perkebunan potensial yang dilakukan kajian yaitu Kayu Manis dan Kopi. Kajian ini akan melakukan identifikasi daerah penghasil terbesar produk perkebunan yang diteliti tersebut. Adapun daerah penghasil terbesar kayu manis adalah kabupaten Kerinci dan penghasil terbesar kopi adalah kabupaten Merangin. 
Adapun tujuan dari panelitian ini adalah (1) menganalisis mendalam tentang produk hasil perkebunan berupa kopi dan kulit manis (2) menganalisis daerah yang disarankan dibuka pasar lelang berdasarkan ketersediaan hasil produksi kopi dan kayu manis.

\section{METODOLOGI PENELITIAN}

\section{Ruang Lingkup Penelitian}

Ruang lingkup kegiatan kajian ini meliputi data komoditas seluruh kecamatan di wilayah Kabupaten Kerinci dan Kabupaten Merangin. Dengan produk unggulan daerah yaitu Kopi (kopi robusta, arabika dan liberika) dan kayu manis. Mengingat kedua komoditi tersebut merupakan komoditi yang menjadi primadona di masing masing daerah dengan keunggulan dan karakteristik spesifik berdasarkan kondisi masing masing daaerah.

\section{Jenis Data}

Jenis data yang digunakan dalam kajian ini adalah data sekunder yang dikumpulkan dari beberapa instansi atau dinas perkebunan yang terkait dengan penelitian.

\section{Metode Analisis Data}

Metode analisis data yang digunakan dalam kajian ini adalah metode Deskriptif Kualitatif dan Deskriptif Kuantitatif. Metode deskriptif kualitatif adalah metode yang digunakan untuk menerangkan keadaan berdasarkan kondisi yang sesungguhnya. Sementara metode deskriptif kuantitatif merupakan metode yang menerangkan suatu kondisi dengan berdasarkan perhitungan angka. Selanjutnya jenis kajian ini adalah bersifat eksploratif dengan menerangkan suatu kondisi atau permasalahan yang baru.

\section{Alat Analisis data}

Alat analisis data yang digunakan dalam penelitian ini adalah model pertumbuhan, produktivitas, dan analisis SWOT, yang didasarkan pada data yang ada dengan beberapa pertimbangan sesuai dengan komoditi yang ada.

\section{HASIL PENELITIAN}

Pada umumnya ada tiga permasalahan utama yang menjadi menyebabkan rendahnya Produksi komoditi unggulan daerah, diantaranya adalah masalah produksi (produktivitas), distribusi hasil produksi, dan nilai tukar petani (harga jual). Ketiga pemasalahan tersebut mempunyai keterkaitan yang sangat erat, yang satu sama lainnya tidak dapat dipisahkan.

Dalam kondisi riel dilapangan menunjukkan bahwa ketika distribusi pemasaran hasil produksi sulit dan harga jual produk rendah maka secara otomatis akan mempengaruhi jumlah produksi yang dihasilkan. Hal ini terjadi karena petani akan mulai berekspektasi bahwa akan 
lebih baik mencari pekerjaan yang lain untuk mencukupi kebituhannya dibandingkan dengan megolah perkebunan yang tidak mencukupi (pendapatan rendah) atau bahkan para petani melakukan alih fungsi lahan dengan menanam jenis tanaman baru yang lebih menguntungkan. Jika hal ini terjadi secara terus menerus maka akan memberikan dampak semakin menurunnya produksi produk unggulan daerah tersebut.

Untuk mengatasi ketiga permasalahan tersebut maka sangat diperlukan campur tangan pemerintah. Baik dalam hal peningkatan produksi, memperpendek distribusi pemasaran dan peningkatan harga jual. Dalam kajian ini akan menyajikan kondisi riel hasil produksi dari beberapa komoditi unggulan yang terpilih yang terdapat pada tiga kabupaten di Provinsi Jambi yaitu Kabupaten Tanjung Jabung Barat, Kabupaten Merangin dan Kabupaten Kerinci.

Adapun komoditi produk unggulan daerah di Kabupaten Tanjung Jabung Barat adalah Kelapa Dalam dan Kopi (Liberika), sementara di Kabupaten Kerinci komoditi unggulannya adalah Kopi Robusta, Kopi Arabika dan Casiavera, sedangkan di Kabupaten Merangin adalah Kopi Kopi Robusta dan Casiavera. Ketiga komoditi ini dipilih menjadi komoditi unggulan didasarkan komoditi yang mempunyai spesifik tersendiri yang dipengaruhi faktor alam dengan jumlah yang banyak dan menjadi mata pencaharian masyarakat.

Dalam analisa penentuan penyediaan pasar lelang untuk komoditi produk unggulan ini didasarkan pada beberapa aspek diantaranya : (1) Kontinuitas Produksi Komoditi (2) harga jual petani (3) distribusi pemasaran hasil produksi dan (4) Hasil produksi yang meliputi; (a) luas lahan tempat produksi yang terdiri dari TMT, TM, dan TR/TT, (b) jumlah produksi pertahun; (c) Produktivitas hasil produksi (kg/ha/Th), (d) Jumlah Petani yang bekerja serta (5) kesepakatan petani untuk komitmen ikut dalam kegiatan lelang. Atas dasar beberapa indikator tersebut nanti akan disimpulkan apakah layak atau tidak untuk disediakan pasar lelang pada masing masing daerah tersebut. Adapun analisis lebih mendalam adalah sebagai berikut:

\section{Informasi dan data hasil perkebunan Komoditi Kopi dan Kayu Manis}

\section{a) Kontinuitas Produksi Komoditi}

1) Komoditi Kopi

Tanaman kopi termasuk pada kelompok tanaman yang berbuah musiman. Dengan penen raya 1 tahun sekali dan kemudian panen biasa sepanjang tahun dengan presentase produksi yang kecil. Pada umumnya lama masa panen tersebut dipengaruhi oleh perawatan, pupuk dan bibit serta kesuburan tanah. Tanaman kopi bisa hidup sampai 100 tahun namun untuk usia produktif dengan jumlah buah terbanyak berada 
dibawah 20 tahun. Sehingga umumnya petani kopi akan melakukan replanting tanaman kopi ketika sudah berumur lebih dari 20 tahun. Hal ini dilakukan karena untuk meningkatkan kualitas dan kuantitas jumlah buah yang diinginkan oleh petani kopi.

Dengan banyaknya jumlah produksi kopi yang mampu dihasilkan secara kontinu setiap tahunnya maka komoditi unggulan ini perlu tempat penampungan atau pemasaran dengan kondisi, sistim pembelian dan harga yang lebih baik dari yang ada saat ini.

\section{2) Komoditi Kayu Manis}

Tanaman kayu manis merupakan tanaman yang yang hanya dapat ditanam pada suhu rata rata 25 derajat dengan batas maks 27 derajat, dengan curah hujan antara 20002500 dengan tingkat kelembaban 70-90 \% dan sinar matahari sekitar 40-70\%. Artinya kondisi ini hanya ada pada Kabupaten Kerinci dan Merangin sehingga dua kabupaten tersebut mampu menghasilkan produk kayu manis yang menjadi komoditi unggulan di Provinsi Jambi.

Tanaman ini merupakan tanaman yang masa panennya hanya satu kali dalam masa tanam. Dan ketika sudah selesai di panen maka tanaman ini harus ditanam kembali. Untuk jenis tanaman ini secara konsep memang tidak bisa berproduksi secara kontinu namun dilapangan dengan jumlah tanaman yang cukup luas dan dipanen secara bergantian maka produksi kayu manis dapat dihasilkan secara kontinu.

Masa panen tenaman casiavera antara 5-20 tahun tergantung pada keinginan para petani untuk melakukan panen. Pada umumnya semakin besar pohon atau lama usia tanaman maka semakin banyak kulit yang dihasilkan demikian juga sebaliknya. Kontinuitas produksi casiavera memang tidak dapat dilakukan namun dari data yang ada menunjukkan bahwa produksi casiavera rata rata pertahun juga cukup tinggi sehingga produk unggulan ini juga sangat membutuhkan tempat penjualan dengan sistim dan harga yang lebih baik dibandingkan dengan sistim penjualan sebelumnya.

\section{b) Harga jual Produk unggulan daerah pada tingkat Petani}

\section{1) Harga Jual Kopi}

Dalam analisa ini harga jual juga merupakan tujuan utama dilaksanakannya kajian ini. Dengan rendahnya harga jual hasil produksi pada tingkat petani maka dampaknya akan menurunkan pendapatan petani dan dalam jangka panjang akan menurunkan 
jumlah produksi sebagai akibat alih fungsi lahan dan berpindah mata pencaharian yang mampu mencukupi untuk kebutuhan hidup para petani.

Berdasarkan informasi yang dilakukan melalui wawancara secara langsung kepada petani kopi maka diperoleh harga kopi per kilogram pada tingkat petani sebesar 28.000/kg. Harga tersebut adalah harga kopi pada jenis kopi dengan kualitas sedang dan dengan kadar air dibawah antara 40-50 persen. Harga tersebut tidak selalu tetap dari waktu ke waktu dalam satu tahun, selain dipengaruhi oleh permintaan, penurunan harga tersebut sering terjadi karena permainan dari para pengumpul yang ingin mengambil keuntungan lebih dari selisih pernjualan kopi. Penurunan harga kopi ini pada umumnya dilakukan ketika terjadi panen raya, sehingga dengan melimpahnya kopi yang siap dijual maka para pengumpul menurunkan harga belinya bahkan sampai 20.000 perkilo.

Hal semacam ini sangat sering terjadi di tingkat petani hal ini dikarenakan ketidakmampuan para petani untuk mencari pembeli yang mampu membeli harga kopi yang mereka produksi dengan harga yang lebih tinggi. Dan umumnya petani hanya pasrah menerima keadaan dengan bergantung pada harga yang ditetapkan para pengumpul. Atas dasar hal tersebut diharapkan dengan adanya pasar lelang akan mampu meningkatkan nilai tukar petani kopi sehingga harga jual dapat lebih tinggi dan cenderung stabil.

\section{2) Harga Jual Kayu Manis}

Harga jual kayu manis pada tingkat petani dibagi menjadi dua kategori yang pertama KA dan KF. Kategori KA dengan ciri ciri ketebalan 1,5-2 mm dengan perkiraan kadar minyak sebesar $1-2$ persen lebih, yang diproduksi dalam bentuk asalan dengan kadar air maksimal 10 persen dihargai sebesar 35.000/kg sementara untuk kayu manis yang basah atau dengan kadar air lebih dari 40 persen harga jualnya hanya 20.000 perkilo. Sedangkan untuk kulit kayumanis dengan kategori KF harga jual untuk kadar 10 persen sebesar 39.000 perkilo. Dan untuk kadar air yang lebih dari 40 persen pada kisaran $24.000-27.000$ perkilo.

Harga tersebut juga dapat berubah sewaktu-waktu sesuai dengan harga yang ditetapkan pengumpul, permintaan barang dari luar dan masa penen yang melimpah. Artinya hampir kondisi tersebut juga sangat tidak menguntungkan bagi petani casiavera dimana harga jual mereka sangat rendah dibandingkan harga jual kayu manis pada tingkat konsumen. Atas dasar hal tersebut dan harapan dari pada petani sangat 
menginginkan adanya tempat penampungan hasil produksi dengan harga dan sistim penjualan yang lebih baik lagi.

\section{c) Distribusi pemasaran Kopi dan Kayu Manis}

Berdasarkan wawancara secara langsung dari para responden (petani, pengumpul, dan pedagang) menyatakan bahwa saluran distribusi penjualan hasil produksi dari Produk unggulan daerah Kopi dan kayu manis pada dua kabupaten masih terlalu panjang, sehingga berdampak pada rendahnya nilai tukai petani.

Distribusi pemasaran yang terjadi di lapangan melalui lebih dari 4 saluran distribusi dimana petani pada umumnya menjual pada pengumpul kecil selanjutnya pengumpul kecil menjual pada agen yang lebih besar lalu dijual pada perusahaan baru dijual pada pedagang kemudian ke pengecer dan baru ke konsumen. Panjangnya saluran distribusi pemasaran tersebut tentu sangat merugikan para petani sehingga perlu adanya campur tangan dari pemerintah untuk memotong rantai distibusi pemasaran tersebut sehingga lebih pendek dan lebih menguntungkan para petani.

Dengan semakin singkatnya alur pemasaran hasil pertanian maka harga jual hasil pertanian dari para petani akan mampu ditingkatkan. Oleh sebab itu sangat perlu pemerintah untuk memfasilitasi alur pemasaran dengan sistim dan harga yang lebih baik dari sebelumnya.

\section{d) Kesepakatan petani mengikuti lelang}

Dari hasil wawancara yang dilakukan secara langsung pada petani baik petani kopi dan petani kayu manis di dua kabupaten yang menjadi lokasi penelitian maka dapat diperoleh kesimpulan bahwa para petani sepakat untuk mengikuti pasar lelang untuk menjual hasil pertanian mereka dengan beberapa catatan diantaranya : transaksi yang terjadi lebih netral dari kecurangan, dan harga jual hasil produksi lebih tinggi dibandingkan dengan harga dari para pengumpul.

Jika pemerintah mampu mencari mitra dalam pasar lelang sehingga mampu membeli hasil produksi lebih tinggi maka kegiatan pasar lelang ini akan memberikan dampak bagi pendapatan para petani.

3. Analisis produk hasil perkebunan berupa kopi dan kayu manis di Kabupaten Merangin dan Kerinci. 


\section{Produk Unggulan Kabupaten Merangin}

\section{a. Analisis Produksi Kopi}

Dilihat dari hasil produksi kopi di Kabupaten Merangin cukup banyak, data menunjukkan lebih dari 6.600 ton pertahun kopi mentah dihasilkan di kabupaten ini. Namun produksi kopi tersebut tidak menyebar secara merata dan hanya 3 kecamatan yang menghasilkan produksi kopi dengan jumlah yang sangat banyak. Ketiga kecamatan tersebut adalah Kecamatan Jangkat, Kecamatan Jangkat Timur dan Kecamatan Lembah Masurai.

Ketiga kecamatan tersebut memang sudah sejak lama mayoritas masyarakatnya mata pencahariaannya bergantung pada perkebunan kopi, maka tidak heran jika produksi kopi pada tiga kecamatan tersebut tinggi. Jika dilihat dari produksi yang dihasilkan di Kabupaten Merangin ada tiga kecamatan yang layak untuk dibuat pasar lelang karena produksi kopi yang dihasilkan jumlahnya banyak dan mampu berproduksi secara kontinu dalam jangka panjang. Untuk lebih jelasnya dapat dilihat pada tabel dibawah ini;

Tabel.1 Jumlah Produksi Kopi di Kabupaten Merangin tahun 2015, 2016 dan 2017

\begin{tabular}{|c|c|c|c|c|c|c|c|}
\hline \multirow{2}{*}{ No } & \multirow{2}{*}{ Kecamatan } & \multicolumn{3}{|c|}{ Produksi (ton) } & \multicolumn{3}{|c|}{ Produktifitas (Kg/Ha/Th) } \\
\hline & & ATAP 2015 & ATAP 2016 & ASEM 2017 & 2015 & 2016 & 2017 \\
\hline 1 & Jangkat & 943 & 961 & 961 & 1.111 & 1.111 & 1.111 \\
\hline 2 & Jangkat Timur & 1.085 & 1.109 & 1.109 & 1.204 & 1.212 & 1.212 \\
\hline 3 & Bangko & 7 & 7 & 7 & 875 & 875 & 875 \\
\hline 4 & Bangko Barat & 4 & 4 & 4 & 800 & 800 & 800 \\
\hline 5 & Nalo Tantan & 2 & 2 & 2 & 667 & 667 & 667 \\
\hline 6 & Batang Masumai & 2 & 2 & 2 & 667 & 667 & 667 \\
\hline 7 & Muara Siau & 37 & 40 & 40 & 787 & 816 & 814 \\
\hline 8 & Lembah Masurai & 4.394 & 4.435 & 4.435 & 996 & 999 & 999 \\
\hline 9 & Sungai Manau & 66 & 37 & 37 & 971 & 974 & 974 \\
\hline 10 & Pangkalan Jambu & 29 & 29 & 29 & 744 & 744 & 744 \\
\hline 11 & Renah Pembarap & 42 & 41 & 41 & 609 & 594 & 594 \\
\hline 12 & Tabir & 30 & 30 & 30 & 682 & 682 & 682 \\
\hline 13 & Tabir Ilir & & & & & & \\
\hline 14 & Tabir Timur & & & & & & \\
\hline 15 & Pemenang & 2 & 2 & 2 & 500 & 500 & 500 \\
\hline 16 & Pemenang Barat & 2 & 2 & 2 & 1.000 & 1.000 & 1.000 \\
\hline 17 & Tabir Ulu & & & & & & \\
\hline 18 & Tabir Selatan & & & & & & \\
\hline 19 & Margo Tabir & & & & & & \\
\hline 20 & Tabir Lintas & & & & & & \\
\hline 21 & Tabir Barat & & & & & & \\
\hline 22 & Tiang Pumpung & 14 & 14 & 14 & 824 & 824 & 824 \\
\hline
\end{tabular}




\begin{tabular}{|r|r|r|r|r|r|r|}
23 & $\begin{array}{l}\text { Pamenang } \\
\text { Selatan }\end{array}$ & & & & & \\
\hline 24 & Renah Pamenang & 1 & 1 & 1 & & 1.000 \\
\hline $\begin{array}{l}\text { Jumlah/Rata } \\
\text { rata }\end{array}$ & $\mathbf{6 . 6 6 0}$ & $\mathbf{6 . 7 1 6}$ & $\mathbf{6 . 7 1 6}$ & $\mathbf{8 2 9}$ & $\mathbf{8 4 2}$ & $\mathbf{8 3 0}$ \\
\hline
\end{tabular}

\section{b) Analisis Produksi Kayu Manis}

Sementara untuk komoditi kayu manis tidak begitu banyak produksinya dan cederung tidak stabil. Karena pada jenis tanaman ini bersifat sekali panen sementara jika luas lahan untuk menanam komoditi ini tidak terlalu luas maka akan sangat berpengaruh pada jumlah produksi yang dipanen. Pada tabel dibawah ini menunjukkan jumlah produksi kayu manis perkecamatan di Kabupaten Merangin. Berdasarkan data yang ada hanya ada satu kecamatan yang mampu memproduksi casiavera lebih dari 1000 ton pertahun yaitu kecamatan lembah masurai. Artinya jika pemerintah ingin membuka pasar lelang untuk komoditi kayu manis di Kabupaten Merangin hanya pada kecamatan Lembah Masurai yang paling tepat, mengingat jumlah produksi dan kontinuitas transaksi akan berlangsung dalam jangka panjang.

Tabel.2. Jumlah Produksi Kayu Manis di Kabupaten Merangin th 2015, 2016 dan 2017

\begin{tabular}{|c|c|c|c|c|c|}
\hline \multirow{2}{*}{ No } & \multirow{2}{*}{ Kecamatan } & \multicolumn{2}{|c|}{ Produksi (Ton) } & \multicolumn{2}{|c|}{ Produktifitas (Kg/Ha/Th) } \\
\hline & & 2016 & 2017 & 2016 & 2017 \\
\hline 1 & Jangkat & 200 & 200 & 1961 & 1.961 \\
\hline 2 & Jangkat Timur & 385 & 385 & 1351 & 1.351 \\
\hline 3 & Bangko & 8 & & 1600 & \\
\hline 4 & Bangko Barat & 12 & 8 & 1500 & 1.333 \\
\hline 5 & Nalo Tantan & & & & \\
\hline 6 & Batang Masumai & 2 & 2 & 1000 & 1.000 \\
\hline 7 & Muara Siau & 120 & 176 & 1237 & 1.419 \\
\hline 8 & Lembah Masurai & 1.426 & 1.426 & 1932 & 1.927 \\
\hline 9 & Sungai Manau & 83 & 125 & 1137 & 1.136 \\
\hline 10 & Pangkalan Jambu & 100 & 103 & 1020 & 1.030 \\
\hline 11 & Renah Pembarap & 102 & 106 & 1074 & 1.093 \\
\hline 12 & Tabir & & & & \\
\hline 13 & Tabir Ilir & & & & \\
\hline 14 & Tabir Timur & & & & \\
\hline 15 & Pemenang & 10 & 10 & 1000 & 1.000 \\
\hline 16 & Pemenang Barat & 3 & & 1500 & \\
\hline 17 & Tabir Ulu & 37 & 37 & 1762 & 1.762 \\
\hline 18 & Tabir Selatan & & & & \\
\hline 19 & Margo Tabir & & & & \\
\hline
\end{tabular}




\begin{tabular}{|r|l|r|r|r|r|}
\hline 20 & Tabir Lintas & & & & \\
\hline 21 & Tabir Barat & 210 & 219 & 1736 & 1.724 \\
\hline 22 & Tiang Pumpung & 56 & 83 & 1514 & 2.243 \\
\hline 23 & Pamenang Selatan & 3 & & 1500 & \\
\hline 24 & Renah Pamenang & & & & \\
\hline & Jumlah & $\mathbf{2 . 7 5 7}$ & $\mathbf{2 . 8 8 0}$ & $\mathbf{1 . 4 2 6 , 5}$ & $\mathbf{1 . 4 5 9}$ \\
\hline
\end{tabular}

\section{Produk Unggulan Kabupaten Kerinci}

\section{a) Analisis Produksi Kopi}

Secara umum produksi kopi Robusta di Kabupaten Kerinci mengalami penurunan meskipun tidak begitu signifikan hal ini mungkin dipengaruhi oleh usia tanaman yang mulai tidak produktif dan juga iklim yang cukup ekstrim. Sehingga sedikit atau banyak tetap mempengaruhi tingkat produktivitas produksi kopi tersebut. Namun terlepas dari semua tersebut, Kabupaten Kerinci masih tetap menjadi sentra utama penghasil kopi terbesar di Provinsi Jambi

Total produksi kopi robusta di Kabupaten Kerinci dalam setiap tahunnya hampir 4000 ton. Dengan Kecamatan Gunung Raya menjadi penyumbang produksi kopi terbesar setiap tahunnya. Produksi kopi di kabupaten ini tersebar hampir diseluruh kecamatan namun hanya ada lima kecamatan yang cukup layak untuk dapat dibuat pasar lelang. Kelima kecamatan tersebut adalah Kecamatan Air Hangat Timur, Kecamatan Danau Kerinci, Kecamatan Keliling Danau, Kecamatan Gunung Raya dan Kecamatan batang Merangin.

Hal yang mendasarinya adalah jumlah produksi kopi yang cukup banyak dihasilkan dalam kurun waktu satu tahun dengan tingkat kontinuitas produksi yang stabil sehingga kegiatan jual beli dipasar lelang akan dapat berjalan dalam jangka waktu yang lama. Sementara untuk kecamatan - kecamatan yang lainnya dengan jumlah produksi kopi yang relative sedikit dapat bergabung pada pasar lelang dikecamatan terdekat. Demikian juga untuk jenis Kopi Arabika yang dengan jumlah produksi tidak begitu banyak.

Tabel.3 Jumlah Produksi Kopi Robusta di Kab. Kerinci tahun 2014- 2017

\begin{tabular}{|c|c|c|c|c|c|c|c|c|c|}
\hline \multirow{2}{*}{ No } & \multirow{2}{*}{ Kecamatan } & \multicolumn{4}{|c|}{ Produksi (Ton) } & \multicolumn{4}{|c|}{ Produktifitas $(\mathrm{Kg} / \mathrm{Ha} / \mathrm{Th})$} \\
\hline & & 2014 & 2015 & 2016 & 2017 & 2014 & 2015 & 2016 & 2017 \\
\hline 1 & Gunung Tujuh & 29 & 32 & 32 & 24 & 784 & 762 & 762 & 762 \\
\hline 2 & Kayu Aro & 27 & 29 & 29 & 17 & 844 & 829 & 829 & 829 \\
\hline 3 & Gunung Kerinci & 30 & 32 & 32 & 29 & 698 & 681 & 681 & 681 \\
\hline 4 & Siulak & 46 & 50 & 50 & 50 & 836 & 820 & 820 & 820 \\
\hline 5 & Air Hangat & 43 & 49 & 49 & 49 & 662 & 653 & 653 & 653 \\
\hline
\end{tabular}




\begin{tabular}{|c|l|r|r|r|r|r|r|r|r|}
\hline 6 & Depati VII & 13 & 17 & 17 & 17 & 867 & 850 & 850 & 850 \\
\hline 7 & Air Hangat Timur & 257 & 257 & 257 & 238 & 784 & 784 & 784 & 784 \\
\hline 8 & Sitinjau Laut & 51 & 54 & 54 & 54 & 680 & 680 & 675 & 675 \\
\hline 9 & Danau Kerinci & 110 & 114 & 114 & 114 & 759 & 759 & 760 & 760 \\
\hline 10 & Keliling Danau & 260 & 262 & 262 & 262 & 778 & 778 & 775 & 775 \\
\hline 11 & Gunung Raya & 2.559 & 2.559 & 2.559 & 2.515 & 890 & 890 & 890 & 890 \\
\hline 12 & Batang Merangin & 523 & 526 & 526 & 526 & 850 & 850 & 850 & 850 \\
\hline & Jumlah & 3948 & 3.981 & 3.981 & 3.895 & 786 & 778 & 777 & 777 \\
\hline
\end{tabular}

Sementara untuk produksi Kopi Arabika di Kabupaten Kerinci tidak begitu banyak dan hanya beberapa kecamatan saja yang menghasilkan produksi kopi tersebut diantaranya Kecamatan Gunung Tujuh, Kecamatan Kayu Aro, Kecamatan Gunung Kerinci, Kecamatan Siulak, Kecamatan Air Hangat dan Kecamatan Gunung Raya.

Tabel.4. Jumlah Produksi Kopi Arabika di Kab. Kerinci tahun 2014 - 2017

\begin{tabular}{|c|l|c|c|c|c|c|c|c|c|}
\hline \multirow{2}{*}{ No } & \multirow{2}{*}{ Kecamatan } & \multicolumn{4}{|c|}{ Produksi (Ton) } & \multicolumn{3}{c|}{ Produktifitas (Kg/Ha/Th) } \\
\cline { 3 - 11 } & & 2014 & 2015 & 2016 & 2017 & 2014 & 2015 & 2016 & 2017 \\
\hline 1 & Gunung Tujuh & 9 & 19 & 25 & 28 & 1.000 & 1.000 & 336 & 338 \\
\hline 2 & Kayu Aro & 15 & 46 & 46 & 67 & 1.000 & 836 & 836 & 838 \\
\hline 3 & Gunung Kerinci & - & 12 & 12 & 15 & - & 600 & 600 & 680 \\
\hline 4 & Siulak & 10 & 14 & 14 & 14 & - & 700 & 700 & 700 \\
\hline 5 & Air Hangat & 2 & 2 & 2 & 2 & 2.000 & 667 & 667 & 667 \\
\hline 6 & Depati VII & - & - & - & - & - & - & - & - \\
\hline 7 & Air Hangat Timur & - & - & - & - & - & - & - & - \\
\hline 8 & Sitinjau Laut & - & - & - & - & - & - & - & - \\
\hline 9 & Danau Kerinci & - & -- & - & - & - & - & - & - \\
\hline 10 & Keliling Danau & - & - & - & - & - & - & - & - \\
\hline 11 & Gunung Raya & 45 & 45 & 45 & 45 & 804 & 804 & 804 & 804 \\
\hline 12 & Batang Merangin & - & - & - & - & - & - & - & - \\
\hline & Jumlah & $\mathbf{8 1}$ & $\mathbf{1 3 8}$ & 144 & 171 & $\mathbf{1 . 2 0 1}$ & $\mathbf{7 6 8}$ & 632 & 639 \\
\hline
\end{tabular}

\section{b) Kayu Manis (Casiavera)}

Selain Kopi di Kabupaten Kerinci juga menjadi pusat penghasil kulit kayu manis terbesar di Provinsi Jambi. Hal ini ditunjukkan dari produksi Casiavera yang dihasilkan di Kabupaten Kerinci yaitu sebanyak 53.000 ton lebih pertahun, dengan jumlah petani lebih dari 12.000 petani.

Pusat produksi casiavera di Kabupaten Kerinci terdapat pada 6 kecamatan dengan produksi casiavera lebih dari 1000 ton pertahun. Yaitu kecamatan gunung tujuh, kayu aro, gunung kerinci, keliling danau, gunung raya dan batang merangin. Dari keseluruhan kecamatan tersebut kecamatan gunung tujuh merupakan kecamatan yang paling tinggi produksinya. 
Sementara untuk kecamatan lain yang tingkat produksinya tidak cukup banyak dapat bergabung pada pasar lelang yang berada di Kecamatan tetangga.

Tabel.5. Jumlah Produksi Kayu Manis di Kabupaten Kerinci tahun 2014- 2017

\begin{tabular}{|c|l|c|c|c|c|c|c|c|c|}
\hline \multirow{2}{*}{ No } & \multirow{2}{*}{ Kecamatan } & \multicolumn{4}{|c|}{ Produksi (Ton) } & \multicolumn{3}{c|}{ Produktifitas (Kg/Ha/Th) } \\
\cline { 3 - 10 } & & & & 2016 & 2017 & 2014 & 2015 & 2016 & 2017 \\
\hline 1 & Gunung tujuh & 1.263 & 1.350 & 1.263 & 1.279 & 1.157 & 1.157 & 1.082 & 1.082 \\
\hline 2 & kayu aro & 3.025 & 3.114 & 3.025 & 3.094 & 1.775 & 1.775 & 1.725 & 1.725 \\
\hline 3 & gunung kerinci & 1.778 & 1.791 & 1.778 & 1.789 & 863 & 863 & 857 & 857 \\
\hline 4 & Siulak & 562 & 570 & 562 & 589 & 676 & 676 & 667 & 667 \\
\hline 5 & air hangat & 81 & 112 & 81 & 92 & 618 & 618 & 448 & 448 \\
\hline 6 & depati VII & 23 & 23 & 23 & 23 & 622 & 622 & 622 & 622 \\
\hline 7 & air hangat timur & 681 & 776 & 681 & 754 & 2.381 & 2.381 & 2.089 & 2.089 \\
\hline 8 & sitinjau laut & 26 & 26 & 26 & 26 & 684 & 684 & 684 & 684 \\
\hline 9 & danau kerinci & 784 & 804 & 784 & 784 & 2.036 & 2.036 & 1.985 & 1.985 \\
\hline 10 & keliling danau & 3.209 & 3.233 & 3.209 & 3.209 & 1.632 & 1.632 & 1.620 & 1.620 \\
\hline 11 & gunung raya & 14.518 & 14.720 & 14.518 & 14.698 & 2.801 & 2.801 & 2.763 & 2.763 \\
\hline 12 & batang merangin & 27.299 & 27.299 & 27.299 & 27.318 & 2.654 & 2.654 & 2.654 & 2.654 \\
\hline & JUMLAH & 53.249 & 53.818 & 53.249 & 53.634 & 1492 & 1492 & 1433 & 1433 \\
\hline
\end{tabular}

\subsection{Analisis SWOT}

Tabel.6. Analisis Matrik Swot Pasar Lelang Bagi Komoditas Unggulan :

\begin{tabular}{|c|c|c|}
\hline Internal & Strenght (S) & Weaknesses (W) \\
\hline Eksternal & $\begin{array}{ll}\text { a. } & \text { Bebas } \\
\text { b. Sederhana } \\
\text { c. Pembentukan harga lebih } \\
\text { transparan } \\
\text { d. Margin yang lebih baik } \\
\text { bagi petani }\end{array}$ & $\begin{array}{l}\text { a. Gagal transaksi (gagal serah, } \\
\text { gagal harga dan gagal kulitas) } \\
\text { b. Keterbatasan infrastruktur } \\
\text { c. Masih kurangnya itikad baik } \\
\text { pelaku pasar lelang } \\
\text { d. Keterbatasan SDM } \\
\text { e. Belum optimalnya peran } \\
\text { pemerintah }\end{array}$ \\
\hline Opportunities & Strategi SO & Strategi WO \\
\hline $\begin{array}{l}\text { a. Terjalinnya kerjasama } \\
\text { antar pasar lelang } \\
\text { b. Terbukanya kesempatan } \\
\text { petani untuk melakukan } \\
\text { pinjaman ke bank }\end{array}$ & $\begin{array}{l}\text { 1. Pemerintah mendorong } \\
\text { terbentuknya kerjasama } \\
\text { antar pasar lelang } \\
\text { 2. Meningkatkan dukungan } \\
\text { dari perbankan }\end{array}$ & $\begin{array}{llr}\text { 1. } & \begin{array}{l}\text { Strategi } \\
\text { infrastruktur }\end{array} & \text { pembangunan } \\
\text { 2. } & \begin{array}{l}\text { Meningkatkan } \\
\text { pemerintah }\end{array} & \text { peran } \\
& \end{array}$ \\
\hline Threat $(\mathrm{T})$ & Strategi ST & Strategi WT \\
\hline $\begin{array}{l}\text { a. Tidak partisipasi } \\
\text { masyarakat yang rendah } \\
\text { b. Lemahnya pengawasan } \\
\text { dari pihak berwenang } \\
\text { terhadap pasca transaksi } \\
\text { c. Ketersediaan komoditas } \\
\text { cukup di pasar lelang }\end{array}$ & 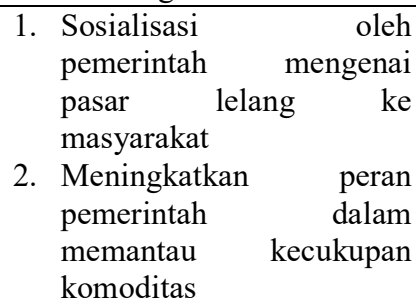 & $\begin{array}{ll}\text { 1. } & \text { Strategi peningkatan kualitas } \\
\text { SDM } & \\
\text { 2. } & \text { Meningkatkan } \\
\text { pemerintah } & \text { peran } \\
\text { pengawasan } & \text { dalam }\end{array}$ \\
\hline
\end{tabular}




\section{Analisis SWOT :}

\section{a. Strenght (Kekuatan)}

- Bebas, pasar lelang diadakan terbuka dan bebas untuk siapa saja baik penyedia komoditas maupun pembeli yang akan membeli komoditas tersebut. Petani yang memiliki ketersediaan komoditi yang cukup dapat masuk ke pasar lelang. Seperti pasar pada umumnya, komoditi yang memiliki kualitas baik yang akan diminati pembeli dan bertahan di pasar lelang.

- Sederhana, Sistem dan mekanisme pasar lelang memerlukan kesederhanaan, dengan keanggotaan berskala nasional yang didukung sistem verifikasi dan akreditasi. Dari segi lokasi, pasar lelang dapat dilaksanakan dimana saja, namun harus tertib dan berkelanjutan, dengan sistem nasional terpusat, sedangkan pelaksanaannya didaerah dilakukan secara desentralisasi. Dengan sistem terpusat secara nasional dimungkinkan dikembangkannya transaksi lelang jarak jauh antar daerah berbasis internet berbiaya efisien yang dalam jangka menengah menuju kepada sistem remote trading

- Pembentukan harga lebih transparan, penawaran dan permintaan dibawa dalam suatu lokasi melalui proses terbuka dan kompetitif sampai terjadi harga, karena komoditi yang diperdagangkan diletakkan secara terbuka memungkinkan pembeli untuk memeriksa komoditi secara detail sebelum terjadi transaksi.

- Margin yang lebih baik bagi petani, petani produsen bersama konsumen sebagai sasaran yang dituju, mendapat harga wajar dengan posisi tawar petani yang lebih baik, sehingga kesejahteraannya meningkat. Petani diberdayakan agar memiliki daya beli memadai untuk mengkonsumsi barang-barang hasil industri dan pada gilirannya mempercepat pertumbuhan ekonomi secara keseluruhan dan berkesinambungan. Pasar lelang diharapkan dapat meningkatkan taraf hidup petani melalui perbaikan mekanisme pembentukan harga komoditas yang dihasilkan melalui transparansi sistem yang dianut tanpa adanya manipulasi informasi pasar. Kualitas komoditas yang diperdagangkan diharapkan meningkat melalui mekanisme pembentukan harga tersebut karena mutu komoditas yang lebih baik akan mendapatkan penawaran yang lebih tinggi dibandingkan yang berkualitas lebih rendah. Jaminan sistematis akan harga yang lebih baik ini akan mendorong petani termotivasi kuat untuk menghasilkan komoditas dengan mutu yang lebih baik agar diterima di pasar domestik maupun pasar ekspor 
c. Weakness (Kelemahan) :

- Permasalahan kegagalan transaksi (gagal serah, gagal harga, gagal kualitas), terjadi karena ketidakmampuan orang yang terlibat untuk menyelesaikan kewajibannya sesuai waktu, harga dan kualitas yang telah disepakati. Gagal serah dapat muncul dikarenakan faktor yang sifatnya alamiah seperti ketidak kondusifan alam dan terjadinya musibah, serta kesalahan dari pihak-pihak yang bertransaksi dalam mengestimasi kondisi yang akan datang. Gagal harga dapat muncul karena adanya pengingkaran kesepakatan terhadap harga yang telah disepakati. Sementara gagal kualitas dapat muncul karena kegagalan panen akibat kondisi cuaca dan iklim yang tidak mendukung serta akibat adanya persepsi yang berbeda antara penjual dan pembeli terhadap kualitas yang ditetapkan. Kegagalan transaksi ini menyebabkan nilai transaksi yang dibukukan pada saat penyelenggaraan pasar lelang cenderung tidak sebesar realisasinya.

- Permasalahan keterbatasan infrastruktur, dalam penyelenggaraan pasar lelang terkait dengan kebutuhan aturan main yang dapat memberi solusi optimum bagi semua pelaku pasar lelang, keterbatasan sarana dan peralatan yang digunakan, keterbatasan dana penyelenggaraan, serta minimnya sarana informasi bagi peserta lelang dalam menaksir harga yang diajukan

- Permasalahan "itikad baik", dari pelaku pasar lelang ditandai dengan keberadaan praktek makelar serta praktek mafia perdagangan yang menyebabkan terjadinya praktek-praktek kolusif dalam penentuan harga produk yang merugikan peserta lelang yang memiliki kekuatan tawar menawar (bargaining position)

- Permasalahan keterbatasan SDM, terkait dengan SDM aparatur yang menjadi fasilitator dan regulator serta SDM peserta pasar lelang. Keterbatasan SDM aparatur muncul seiring dengan belum terlembaganya kompetensi aparatur penyelenggara pasar lelang mencakup skill, knowledge dan attitude menjadi syarat minimum kualifikasi aparatur untuk dapat menyelenggarakan pasar lelang dengan efektif dan efisien. Keterbatasan SDM peserta pasar lelang terkait dengan keterbatasan kemampuan dalam menganalisis situasi pasar masa depan (forward) khususnya menyangkut kemampuan dalam mengestimasi resiko dan tingkat harga di masa depan.

- Permasalahan belum optimalnya peran pemerintah, sebagai regulator terkait dengan kebijakan yang mengatur penyelenggaraan pasar lelang yang terkesan belum terintegerasi baik dengan kebijakan pemerintah lainnya. Sementara sebagai fasilitator 
terkait dengan masih minimnya peran pemerintah dalam penyediaa sarana dan prasarana karena keterbatasan anggaran yang dimiliki.

d. Opportunity (Peluang)

- Terjalinnya kerjasama dengan pasar lelang, mengapa kerjasama antar penyelenggara pasar lelang diperlukan ? ada beberapa alasan yaitu ditinjau dari (1) perspektif ekonomi, (2) perpektif yuridis, (3) perspektif administrative. (1) Perspektif Ekonomi, keberadaan pasar lelang diharapkan dapat memberikan kontribusi yang berarti bagi perekonomian. Dari sisi perekonomian regional, kerjasama antar pasar lelang memberikan beberapa peran antara lain; pertama, sebagai aktivitas meningkatkan perdagangan. Kedua, kerjasama intra regional di era otonomi daerah dapat memacu perekonomian daerah. Ketiga, keuntungan ekonomis dalam integrasi pasar lelang sebagai dampak dari adanya "economic of scope", dimana lebih menguntungkan untuk mengintegrasikan system yang sejalan dengan mengoptimalkan sumberdaya pasar lelang yang ada baik berupa infrastrukur maupun sumber daya manusia. Keempat, optimalisasi antar pasar lelang dapat terjadi jika terjadi integrasi antar pasar lelang dimana setiap pasar lelang dapat saling menyeimbangkan posisi supply dan demand dengan bantuan pasar lelang yang lain.(2) Perspektif Yuridis, terkait dengan diberlakukannya Undang-Undang 32 Tahun 2004 tentang pemerintah daerah dimana dalam salah satu pasalnya yaitu pasal 195 ayat 1 menyatakan bahwa dalam rangka meningkatkan kesejahteraan rakyat, daerah dapat mengadakan kerjasama dengan daerah lain yang didasarkan pada pertimbangan efisiensi dan efektivitas pelayanan public, sinergi dan saling menguntungkan. Mengacu pada ketentuan tersebut, maka pasar lelang merupakan salah satu instrument yang dapat digunakan untuk meningkatkan mekanisme pasar yang fleksibel agar mampu mengantisipasi terjadinya ketidaksempurnaan dan inefisiensi kerja institusi pasar. Penguatan institusi pasar ditujukan untuk menciptakan iklim yang kondusif bagi kekuatan usaha yang kompetitif sehingga meningkatkan daya saing nasional berbasis efisiensi. Berdasarkan hal tersebut maka pengembangan pasar lelang merupakan hal yang bersifat strategis untuk dilakukan. (3) Perspektif administrasi, kerjasama antar penyelenggara pasar lelang diperlukan dikaitkan dengan kebutuhan akan pengaturan dalam pelaksanaan system keanggotaan secara nasional. Pengaturan ini meliputi standar/etika yang harus dipenuhi oleh seorang anggota untuk dapat mengikuti lelang secara nasional, serta mekanisme system yang diperlukan dalam pelaksanaannya. 
- Terbukanya kesempatan petani untuk melakukan pinjaman ke bank. Pemerintah selalu mendorong berbagai pihak untuk meningkatkan kesejahteraan petani diantaranya kemudahan akses permodalan bagi petani. Karena untuk mencapai hasil panen yang diharapkan petani membutuhkan modal yang cukup karena dapat untuk mengatasi kebutuhan akan benih, pupuk, dan segala hal yang berhubungan dengan pertanamanpun dapat teratasi. Hanya saja implementasi pemberian kredit belum terpenuhi dengan baik. Banyak factor yang menyebabkan kurangnya perhatian perbankan terhadap permodalan petani, diantaranya (1) profesi petani kurang mendapat kepercayaan dari bank untuk mendapatkan suntikan dana. Hal ini dikarenakan penghasilan petani dinilai terlalu kecil, (2) petani tidak memiliki agunan yang memadai untuk jaminan pinjaman. Bahkan, berbagai kredit program yang dikembangkan untuk usaha pertanian seperti Kredit Ketahanan Pangan-Energi (KKP-E), Kredit Pengembangan Energi Nabati dan Revitalisasi Perkebunan (KPEN-RP), Kredit Usaha Pembibitan Sapi (KUPS) dan Kredit Usaha Rakyat (KUR), perkembangannya masih jauh dari harapan. Meski pemerintah telah berkali-kali menyatakan pinjaman KUR bisa tidak pakai agunan, namun dalam pelaksanaannya, bank tidak akan memberi kredit kepada petani bila tidak ada agunan. Dengan adanya pasar lelang terjadi kontrak antara penjual dan pembeli. Kontrak ini dapat dijadikan agunan untuk melakukan pinjaman. Nilai yang tertera di kontrak dapat dijadikan patokan bagi pihak bank untuk menentukan besarnya pinjaman yang diberikan kepada petani. Bagi perbankan, ada jaminan penyaluran kredit yang lebih aman, karena adanya kontrak jual beli.

d. Threats (Ancaman) :

- Tingkat partisipasi masyarakat yang rendah, Partisipasi masyarakat dapat dilihat dari tingkat kehadiran pelaku bisnis di pasar lelang. Belum terbentuknya keanggotan yang tetap sesuai dengan anjuran dari pihak penyelenggara mengakibatkan partisipasi pelaku atau peserta pasar lelang masih rendah. Sehingga hal ini menuntut sosialisasi yang lebih maksimal terhadap peran dan manfaat perdagangan lewat pasar lelang. Jika ditinjau dari fenomena gagal serah dan gagal bayar hal ini menunjukkan bahwa etika bisnis dari pelaku pasar lelang masih rendah.

- Lemahnya pengawasan dari pihak berwenang terhadap pasca transaksi. Meski terjadi transaksi perdagangan dalam pasar lelang, namun, terjadinya gagal bayar maupun gagal serah membutuhkan pengawasan dari pihak penyelenggara khususnya dalam hal 
penyerahan barang di gudang pembeli dan pengawasan produk yang akan dikirim oleh pihak penjual. Fenomena gagal bayar dan gagal serah merupakan perwujudan dari kredibelitas dan integritas pelaku pasar lelang yang masih rendah.

Strategi :

- Strategi SO (kekuatan - peluang) :

- Pemerintah harus berupaya mendorong pembentukan kerjasama antar pasar lelang melalui kemudahan regulasi dan sebagai fasilitator kerjasama tersebut. Hal ini dikarenakan manfaat yang diperoleh dari adanya kerjasama antar pasar lelang yang cukup besar yang dapat memberikan kontribusi yang berarti bagi perekonomian.

- Pemerintah harus melibatkan seluruh stake holder untuk kelancaran penyelenggaraan pasar lelang. Butuhnya dukungan permodalan bagi petani untuk mengatasi kebutuhan akan benih, pupuk, dan segala hal yang berhubungan dengan pertanaman. Hal ini penting mengingat kecukupan komoditas yang dijual pada pasar lelang sangat mempengaruhi keberhasilan penyelenggaraan pasar lelang tersebut. Oleh karena itu pihak perbankan harus melonggarkan urusan persyaratan pinjaman yang dilakukan oleh petani. Agunan yang disyaratkan dapat berupa kontrak kerja antara petani sebagai penjual dan pembeli yang terjadi di pasar lelang. Pemerintah perlu menjamin bahwa kontrak kerja yang berlangsung akan berjalan sebagaimana mestinya.

b. Strategi WO (kelemahan - peluang) :

- Permasalahan keterbatasan infrastruktur dalam penyelenggaraan pasar lelang terkait dengan kebutuhan aturan main yang dapat memberi solusioptimum bagi semua pelaku pasar lelang, keterbatasan sarana dan peralatan yang digunakan, keterbatasan dana penyelenggaraan, serta minimnya sarana informasi bagi peserta lelang dalam menaksir harga yang akan diajukan. Lokasi dari pasar lelang ini sendiri sebaiknya di lokasi yang terjangkau oleh sentra-sentra produksi komoditas yang sejenis dalam satu provinsi. Pasar lelang dianggap menjadi fasilitator dan intermediasi antar petani (gapoktan) dan pembeli baik pedagang pengecer, pengumpul, pedagang besar dan konsumen akhir. Jadi saluran pemasaran dapat lebih pendek dan transparan. Selain itu penerapan Sistem Resi Gudang. Dengan metode Sistem Resi Gudang (SRG), petani dapat menyimpan produknya ke pengelola gudang yang ditandai dengan bukti penyimpanan dalam bentuk resi gudang. Selanjutnya resi tersebut dapat dijadikan 
jaminan untuk mendapatkan pembiayaan dari lembaga keuangan. Perlu pembangunan infrastruktur ini agar metode SRG dapat terlaksana.

- Pemerintah harus membuat kebijakan yang mengatur penyelenggaraan pasar lelang yang terintegerasi baik dengan kebijakan pemerintah lainnya. Hal ini agar penyelenggaraan pasar lelang tidak tumpang tindih kebijakan dengan kegiatan lainnya. Selain itu perlu dukungan anggaran untuk pembangunan sarana dan prasarana penyelenggaraan pasar lelang agar lancer dan mencapai sasaran yang ditetapkan.

c. Strategi ST (kekuatan - ancaman):

- Sosialisasi oleh pemerintah mengenai pasar lelang ke masyarakat harus gencar dilakukan. Mekanisme pembentukan harga transparan dapat terwujud salah satunya dengan kegiatan pasar lelang. Melalui informasi yang lengkap baik tentang harga, mutu dan kuantitas, sehingga biaya transaksi dianggap nol dan pasar adalah sebagai solusi yang efisien. Demikian pula dalam hal penemuan harga; terjadi proses kesepahaman antara penjual dan pembeli pada tingkat harga pasar yang disepakati yang memungkinkan terjadinya transaksi. Penjual (produsen) dan pembeli (pengguna) dapat bernegosiasi secara langsung, menyamakan status dan posisi tawar, sampai terjadinya kesepakatan harga (dalam wujud kontrak tertulis). Melalui pasar lelang daya saing hasil produksi petani di pasar nasional akan meningkat sehingga berimbas ke kesejahteraan petani produsen.

- Untuk mengatur kecukupan komoditas di pasar lelang maka perlu kebijakan pemerintah untuk mengatur jadwal penyelenggaraan pasar lelang. Penentuan hari lelang memiliki kecenderungan peserta lelang untuk keikutsertaanyya dalam pasar lelang. Hal ini dikarenakan bagi peseta lelang perlu mengatur perencanaan waktu yang tepat untuk terlibat dalam pasar lelang. Misalnya bagi produsen atau penjual, perencanaan waktu lelang akan mempengarhi waktu penyerahan komoditi yang disetujui dalam transaksi, yang selanjutnya mempengaruhi pola dan waktu tanam. Waktu lelang yang terjadwal memberikan kemudahan bagi penjual maupun pembeli untuk merencanakan kesediaan dan pasokan yang mereka miliki. Kebijakan waktu lelang ini merupakan upaya untuk menjaga kecukupan komoditi yang dijual di pasar lelang.

d. Strategi WT (kelemahan - ancaman) :

- Permasalahan keterbatasan SDM terkait dengan SDM aparatur yang menjadi fasilitator dan regulator serta SDM peserta pasar lelang. Keterbatasan SDM aparatur muncul 
seiring dengan belum terlembaganya kompetensi aparatur penyelenggara pasar lelang mencakup skill knowledge dan attitude yang menjadi syarat minimum kualifikasi aparatur untuk dapat menyelenggarkan pasar lelang dengan efektif dan efisien. Keterbatasan SDM peserta pasar lelang terkait dengan keterbatasan kemampuan dalam menganalisis situasi pasar masa depan (forward) khususnya menyangkut kemampuan dalam mengestimasi resiko dan tingkat harga di masa depan.

- Membuat kebijakan yang mengatur secara khusus tentang persyaratan, hak dan kewajiban serta kode etik bagi penyelenggara pasar lelang. Hal ini dimaksudkan agar tidak terjadi eksploitasi pasar oleh penyelenggara pasar lelang serta sebagai upaya untuk mengembangkan sisi positif dari penyelenggaraan pasar lelang. Bagi sector swasta, keuntungan ekonomis yang muncul karena bertindak sebagai penyelenggara pasar lelang tentulah merupakan prasyarat utama, sehingga perlu bagi pemerintah untuk menyampaikan sisi positif penyelenggaraan pasar lelang sebagai upaya untuk menarik minat calon peserta lelang. Nantinya ketika dunia usaha telah menyadari keuntungan ekonomis pasar lelang maka pihak swasta dengan sendirinya akan tertarik untuk menjadi penyelenggara pasar lelang.

\section{KESIMPULAN DAN SARAN}

\section{Kesimpulan}

Dari hasil analisis kajian dengan berdasarkan: (1) Kontinuitas Produksi Komoditi (2) harga jual petani (3) distribusi pemasaran hasil produksi, (4) Hasil produksi dan (5) kesepakatan petani maka dapat disimpulkan sebagai berikut :

1 Pengadaan pasar lelang dapat dilakukan ditingkat kecamatan dengan pertimbangan jumlah produksi yang dihasilkan dalam skala yang besar dan kontinu.

2 Lokasi rencana pembentukan pasar lelang untuk Komoditas Kopi disarankan:

- Kabupaten Tanjung Jabung Barat di Kecamatan Bram Itam, Kuala Betara, dan Pengabuan.

- Kabupaten Merangin di Kecamatan Gunung Tujuh, Kayu Aro, Gunung Kerinci, Keliling Danau, Gunung Raya dan batang Merangin

- Kabupaten Kerinci di Kecamatan Air Hangat Timur, Danau Kerinci, Keliling Danau, Gunung Raya, dan Batang Merangin.

3 Lokasi rencana pembentukan pasar lelang untuk Komoditas kayu manis disarankan: 
- Kabupaten Merangin di Kecamatan Lembah Masurai

- Kabupaten Kerinci di Kecamatan Gunung Tujuh, Kayu Aro, Gunung Kerinci, Keliling Danau, Gunung Raya dan Batang Merangin.

\section{Saran}

Pelaksanaan rencana kegiatan ini harus segera dilaksanakan agar mempercepat meningkatkan pendapatan masyarakat dan menyelamatkan produk unggulan daerah.

\section{DAFTAR PUSTAKA}

Alamsyah, Z. (2014). Analisis Integrasi Pasar Pinang Kabupaten Tanjung Jabung Barat. Jurnal Ilmiah Sosio-Ekonomika Bisnis, 17(2).

Badan Litbang Pertanian . 2009. Mengenal Tanaman perkebunan di Lingkungan Sekitar Kita. Jakarta.

Hakim Luchman. 2015. Rempah dan Herba Kebun-Pekarangan Rumah Masyarakat: Keragaman, sumber fitofarmaka dan wisata kesehatan-kebugaran. Yogyakarta. Diandra Creative.

Irawan, A., \& Rosmayanti, D. (2016). Analisis Integrasi Pasar Beras di Bengkulu. Jurnal Agro Ekonomi, 25(1), 37-54.

Irmanelly, I., \& Soleh, A. (2013). Analisis Sektor Unggulan dan Hubungannya dengan Ketenagakerjaan dan Kemiskinan di Provinsi Jambi. Jurnal Development, 1(1), 15-43.

Noor Faizal Henry. 2015. Ekonomi Publik. Jakarta. Indeks Penerbit.

Tim Karya Tani Mandiri. 2018. Rahasia Sukses Budidaya Kopi. Bandung. Nuansa Aulia.

Simpala M Mawardin. 2018. Jejak Sukses Pengusaha Kelapa Indonesia. Yogyakarta. Andi

Saptana, S., \& Saliem, H. P. (2015). Tinjauan konseptual makro-mikro pemasaran dan implikasinya bagi pembangunan pertanian. In Forum Penelitian Agro Ekonomi (Vol. 33, No. 2, pp. 127-148). Indonesian Center for Agricultural Socioeconomic and Policy Studies.

Soleh, A. (2018). Peranan Dan Kontribusi Sub Sektor Perkebunan Di Provinsi Jambi. Jurnal Ilmiah Universitas Batanghari Jambi, 18(1), 143-151.

Stevan, J., \& Alamsyah, Z. (2015). Analisis Efektivitas Pasar Lelang Karet di Kabupaten Bungo Provinsi Jambi. Jurnal Ilmiah Sosio-Ekonomika Bisnis, 18(1).

Zakaria, A., Aditiawati, P., \& Rosmiati, M. (2018). Strategi Pengembangan Usahatani Kopi Arabika (Kasus pada Petani Kopi Di Desa Suntenjaya Kecamatan Lembang Kabupaten Bandung Barat, Provinsi Jawa Barat). Jurnal Sosioteknologi, 16(3), 325-339. 